\title{
Pengaruh Pemberian Sari Buah Kersen terhadap Kadar Asam Urat pada Penderita Hiperurisemia
}

\author{
Himeldah Isa Mahendra', Puspito Arum² \\ 1,2Progam Studi Gizi Klinik Jurusan Kesehatan Politeknik Negeri Jember \\ *Email: himeldaih06@gmail.com
}

\begin{abstract}
Hyperuricemia is a health condition characterized by increasing uric acid levels in the body. Jamaican cherry (Muntingia calabura) is vitamin C containing fruit that have lowering-purine effect. The aim of this study was to determine the effect of Kersen (Muntingia calabura) extract on uric acid levels. This was experimental study with pretest-posttest control group design. Male and female aged above 50 years and not taking vitamins were reqruites as subjects. In this study, the subjects were divided into control and treatment group with the total of 17 subjects for each group. The subjects consume 40.5 grams Kersen. The uric acid level was measured by helath professionals using Easy Touch. The diference of uric acid level were analized using Wilcoxon test and Man-Whitney test, and the correlation and effect of Kersen were analyzed using Partial Correlation test and Linear Regression Test. The results show that uric acid levels in the treatment group were above normal as well as the control group because at the beginning of the study there were differences in the subject selection of each group. The results show that there is an effect of granting cherry juice to uric acid level ( $p$ 0.004).
\end{abstract}

Keywords: Gout, Hyperuricemia, Cherry Fruit, Vitamin C.

\section{PENDAHULUAN}

Penyakit tidak menular umumnya mempunyai durasi yang panjang dan berkembang. Salah satu penyakit tidak menular yaitu asam urat atau arthritis gout (Kemenkes, 2013). Metabolisme Purin dapat menghasilkan produk berupa asam urat. Terdapat dua jenis asam urat yaitu endogen (dalam tubuh) dan eksogen (luar tubuh). Kadar normal asam urat pada wanita yaitu $2,4-5,7 \mathrm{mg} / \mathrm{dL}$, pada lakilaki dewasa 3,4-7,0 mg/dL pada anak-anak 2,8 $-4,0 \mathrm{mg} / \mathrm{dl}$. Asam urat dalam keadaan normal berperan penting dalam metabolisme tubuh sedangkan jika berlebih menyebabkan adanya kerusakan sel tubuh (Lingga, 2012). Suatu keadaan tingginya kadar asam urat yang disebabkan oleh adanya gangguan metabolik disebut dengan hiperurisemia. Tingginya kadar asam urat tidak dapat termetabolisme dengan sempurnah, hal ini yang menyebabkan terjadinya peningkatan kadar asam urat dalam (Lingga, 2012).

Prevalensi penyakit sendi di Indonesia tahun 2018 sebesar 7,3 \% (Riskesdas, 2018) dan di Jawa Timur yaitu 26,9\%, prevalensi tersebut lebih tinggi daripada Jawa Tengah (25,5\%), DI Yogyakarta (22,7\%), DKI Jakarta $(21,8 \%)$, dan Banten (20,6\%) (Riskesdas, 
2013). Berdasarkan prevalensi penyebab terjadinya penyakit asam urat berhubungan dengan usia, jenis kelamin, obesitas, konsumsi alkohol, riwayat medis dan konsumsi purin (Untari dkk, 2017). Peningkatan kadar asam urah darah yang berasal dari makanan yang memiliki kadar purin tinggi menjadi penyebab yang sering terjadi dimasyarakat.

Pencernaan protein akan menghasilkan purin, konsumsi makanan yang mengandung tinggi purin menyebabkan adanya penumpukan purin yang berlebih sehingga tidak dapat termetabolisme dengan sempurna dan terbentuknya hiperurisemia, sehingga mengakibatkan kristal urat menumpuk dalam tubuh (Risnanto dan Insani, 2014). Hiperurisemia yang memiliki gejala yaitu timbulnya rasa nyeri pada sendi, untuk menggurangi rasa nyeri biasanya masyarakat memilih mengonsumsian obat tanpa resep dokter, sekitar $86,1 \%$ orang memilih untuk mengonsumsi obat tanpa resep dokter (Riskesdas, 2013). Pengobatan asam urat dapat berupa farmakologis dan non farmakologis. Pengobatan farmakologis dapat berupa obat yang dapat mengurangi rasa nyeri dan sedangkan non farmakologis dapat memanfaatkan tumbuhan atau tanaman yang ada di sekitar yang memiliki manfaat. Masyarakat lebih memilih mengonsumsi obat di bandingkan dengan mengonsumsi tumbuhan herbal atau tradisional. Menurunkan rasa nyeri dengan menggunakan obat tidak dianjurkan jika di konsumsi secara terus menerus Jurnal Gizi Unimus Vol 10 No 12021 dikarenakan dapat menyebabkan adanya efek samping. Obat alloppurinol biasanya di pilih untuk menghambat pembentukan asam urat di dalam tubuh. Allopurinol berkerja dengan cara menahan atau menghambat adanya enzim xantin oksidase, obat ini akan menghambat peningkatan kadar asam urat agar tidak terjadi peradangan sendi (Amina, 2012). Efek samping ketika mengonsumsi allopurinol secara jangka panjang dapat menyebabkan adanya kerusakan hati, terganggunya pencernaan, berkurangnya sel darah putih dan terjadinya perubahan warna kulit yang disebut dengan ruam kulit. Terjadinya efek samping mengonsumsi obat lebih besar dibandingkan dengan mengonsumsi tumbuhan tradisional (Kemenkes, 2007).

Tumbuhan tradisional merupakan obat yang berasal dari masyarakat yang berasal dari tumbuhan atau gabungan beberapa bahan yang sudah digunakan secara turun menurun yang diberikan oleh nenek moyang yang didilakukan sesuai dengan aturan yang dilakukan dimasyarakat tersebut (Permenkes, 2012). Bahan alternatif dalam menurunkan kadar asam urat dalam tubuh yaitu berupa buah kersen. Pemilihan buah kersen dipilih sebagai cara untuk membantu menurunkan kadar asam urat dikarenakan buah kersen merupakan buah rendah purin. Kandungan dalam buah kersen berupa air, protein, serat, lemak, karbohidrat, kalsium, besi, fosfor, karoten, tiamin, riboflavin, niasin dan kandungan vitamin $\mathrm{C}$ (Olivia, 2014).

Buah kersen juga vitamin $\mathrm{C}$ sebesar 80,5 
mg pada setiap 100 gram buah kersen (Pangkal Ide, 2012). Vitamin C sangat baik untuk asam urat dikarenakan vitamin $\mathrm{C}$ dapat membantu produksi kolagen. Kolagen dapat rusak disebabkan oleh adanya penumpukan asam urat dan monosodium. Kekurangan kadar kolagen dapat menyebabkan sendi terasa sakit (Lingga, 2012). Buah kersen juga memiliki kandungan flavonoid yaitu ektrak etil asetat dan etanol serta memiliki senyawa fenol yang merupakan antioksidan sebagai pencegah radikal bebas (Sanet dkk, 2017). Kandungan pada buah kersen yang baik untuk kesehatan tidak seimbang dengan pengetahuan pengolahan tentang buah kersen pada masyarakat.

Kurangnya pengetahuan pengolahan buah kersen ini menyebabkan produk yang terbuat dari buah ini tidak begitu ketahui oleh masyarakat. Selama ini pohon kersen hanya dianggap sebagai pohon untuk berteduh karena sering dijumpai di tepi jalan dan buahnya hanya digunakan sebagai makanan burung. Penderita asam urat dianjurkan mengonsumsi 9 buah kersen setiap 3x hari sekali untuk menghilangkan rasa nyeri (Simatupang, 2011). Buah kersen ini memiliki masa daya simpan yang pendek dikarenakan buah kersen mengandung kadar air yang cukup banyak. Konsumsi buah dan sayur pada masyarakat indonesia sebesar 93,55 pada tahun 2013 (Riskesdas, 2013). Hasil dari penyaringan buah kersen disebut sebagai sari buah kersen.. Antioksidan yang berupa flavonoid, fenol dan vitamin $\mathrm{C}$ yang ada pada buah kersen dapat Jurnal Gizi Unimus Vol 10 No 12021 dijadikan sebagai cara alternatif untuk mengurangi kadar asam urat.

Penelitian ini juga dilakukan menjawab adanya pengaruh dari buah kersen terhadap kadar asam urat dan sebagai inovasi terbaru cara mengonsumsi buah kersen. Konsumsi sari buah kersen selain kandungan buahnya yang bermanfaat bagi tubuh, juga karena peneliti ingin membuat produk olahan pangan dari buah kersen yang instan dan dapat dikonsumsi sewaktu-waktu oleh masyarakat tanpa perlu mencari dan menghindari buah kersen layu ketika sudah lama dibiarkan. Tujuan dari penelitian yaitu untuk mengetahui adanya pengaruh pemberian sari buah kersen terhadap kadar asam urat pada penderita hiperurisemia.

\section{METODE PENELITIAN}

Bahan yang digunakan yaitu buah kersen matang dan segar. Alat yang digunakan yaitu timbangan digital, sendok makan, penyaring, baskom, gelas ukur, mika plastik, dan pisau.

\section{Pembuatan Sari Buah Kersen}

Pembuatan sari buah kersen dilakukan dengan cara mencari buah kersen yang masih segar lalu dilakukan pencucian buah dengan menggunakan air mengalir. Setelah dicuci hingga bersih buah kersen diperas menggunakan penyaring hingga menjadi kental dan kulit buah kersen menjadi halus. Sari buah kersen yang sudah jadi ditimbang menggunakan timbangan elektronik dan dimasukan kedalam mika kecil sebanyak 40,5 
gram. Setelah dimasukkan kedalam mika, sari buah kersen ditutup menggunakan penutup mika. Setelah semua selesai buah kersen dibagikan kepada subjek dalam keadaan masih segar.

Penelitian merupakan jenis penelitian ekperimen dengan desain Pre test Post test Control Group. Rancangan menggunakan kelompok kontrol dan kelompok perlakuan. Data subjek diambil melalui klinik Suherman Jember dan dilakukan intervensi pada rumah masing-masing subjek. Penelitian terlaksanakan pada bulan Desember 2019. Kriteria subjek berupa subjek yang berusia diatas 50 tahun, subjek dengan kadar asam urat laki-laki yang memiliki kadar asam urat $>7$ $\mathrm{mg} / \mathrm{dl}$ dan pada wanita $>5,7 \mathrm{mg} / \mathrm{dl}$, tidak dalam keadaan rawat inap, subjek yang mengonsumsi obat, dan subjek yang tidak dalam keadaan komplikasi serta tidak mengonsumsi suplemen vitamin C. Jumlah subjek penelitian sebanyak 34 orang dengan menggunakan teknik Purposive Sampling. Sampel darah subjek pada saat awal dan akhir diambil untuk melihat adanya pengaruh sari buah kersen terhadap kadar asam urat subjek. Subjek mengkonsumsi sari buah kersen di rumah masing- masing. Sari buah kersen diantar oleh peneliti selama 7 hari sebanyak 40 gram (1 hari sekali) pada kelompok perlakuan. Kelompok kontrol diberikan air mineral 1 kali sehari selama 7 hari. Data yang diambil dalam penelitian ini berupa usia, jenis kelamin, asupan makanan dan aktifitas fisik. Data diperoleh dengan teknik wawancara menggunakan panduan kuisioner. Pada kedua kelompok subjek dilakukan recall sebanyak $3 x$ dalam seminggu yang berupa 2 hari kerja dan 1 hari libur. Pengambilan sample darah menggunakan alat Easy Touch yang dilakukan oleh tenaga medis.

Variabel yang dikumpulkan yaitu nama, umur, jenis kelamin, pola makan, aktifitas fisik dan konsumsi obat lain penderita hiperurisemia. Untuk mengetahui pengaruh pemberian sari buah kersen terlebih dahulu dilakukan uji beda pada sebelum dan sesudah pada setiap kelompok menggunakan analisis uji wilcoxon. Sedangkan uji uji Mann- Whitney guna untuk mencari perbedaan kadar asam urat pada antar kelompok. Mencari adanya hubungan antara kadar asam urat dengan sari buah kersen dilakukan menggunakan uji Korelasi Parsial, setelah data diketahui memiliki hubungan maka dilanjutkan dengan mencari adanya pengaruh konsumsi sari buah kersen dengan kadar asam urat dilakukan menggunakan uji Regresi Linier.

HASIL DAN PEMBAHASAN

Karakteristik Subjek 
Tabel 1. Karakteristik Subjek

\begin{tabular}{|c|c|c|c|c|c|}
\hline \multirow{2}{*}{ Karakteristik } & \multicolumn{2}{|c|}{$\begin{array}{l}\text { Kelompok } \\
\text { Kontrol }\end{array}$} & \multicolumn{2}{|c|}{$\begin{array}{l}\text { Kelompok } \\
\text { Perlakuan }\end{array}$} & \multirow[t]{2}{*}{$\begin{array}{l}\mathrm{p} \\
\text { value }\end{array}$} \\
\hline & $\mathrm{n}$ & $\%$ & $\mathrm{n}$ & $\%$ & \\
\hline Usia & & & & & 0.05 \\
\hline 50-60 tahun & 11 & 64.7 & 16 & 94.1 & \\
\hline $61-70$ tahun & 5 & 29.4 & - & - & \\
\hline $71-80$ tahun & 1 & 5.9 & 1 & 5.9 & \\
\hline Jenis Kelamin & & & & & 0.672 \\
\hline Perempuan & 14 & 82.4 & 13 & 76.5 & \\
\hline Laki-laki & 3 & 17.6 & 4 & 23.5 & \\
\hline Aktifitas Fisik & & & & & 0.85 \\
\hline Ringan & 6 & 35.3 & 8 & 47.1 & \\
\hline Sedang & 11 & 64.7 & 5 & 29.4 & \\
\hline Berat & - & - & 4 & 23,5 & \\
\hline \multicolumn{6}{|l|}{ Asupan Makanan } \\
\hline Energi & \multicolumn{2}{|c|}{$3080 \pm 407.99$} & \multicolumn{3}{|c|}{$3199 \pm 547.44 \quad 0.77$} \\
\hline Protein & \multicolumn{2}{|c|}{$120.15 \pm 31.02$} & \multicolumn{2}{|c|}{$112.48 \pm 17.17$} & 0.408 \\
\hline Lemak & \multicolumn{2}{|c|}{$99.42 \pm 22.18$} & \multicolumn{2}{|c|}{$85.12 \pm 31.88$} & 0.04 \\
\hline Karbohidrat & \multicolumn{2}{|c|}{$414 \pm 1.18$} & \multicolumn{3}{|c|}{$461.86 \pm 78.43$} \\
\hline
\end{tabular}

Berdasarkan Tabel 1 karakteristik diatas didapatkan hasil pada faktor karakteristik usia dengan nilai sebesar 0,050 yang menunjukan adanya perbedaan yang menunjukkan bahwa data karakteristik usia memiliki perbedaan pada antar kelompok, hal ini dapat disebabkan karena data karakteristik usia pada antar kelompok tidak homogen. Pada karakteristik usia dibagi menjadi 3 kelompok umur yaitu 50 hingga 60 tahun, 61 hingga 70 tahun dan 71 hingga 80 tahun. Pada kelompok kontrol dan kelompok perlakuan lebih banyak jumlah subjek yang berusia antara 50-60 tahun. Sama halnya dengan penelitian yang dilakukan Aryanti (2018) penelitian dilakukan dengan mengunakan subjek udia 40-50 tahu keatas. Hasil dari adanya hubungan usia dengan kadar asam urat sama halnya dengan penelitian Lioso dkk (2015) yang mengatakan kadar asam urat pasien dengan usia $>40$ lebih tinggi dibandingkan dengan pasien dengan usia $<40$ tahun. Karuniawati (2018) menyatakan adanya pengaruh antara usia dengan kadar asam urat dengan nilai sig hasil 0,000 .

Karakterikstik jenis kelamin didapatkan $\mathrm{p}$ value sebesar 0,672 yang menunjukan tidak berbeda signifikan dan menunjukkan bahwa data karakteristik jenis kelamin memiliki perbedaan pada antar kelompok, hal ini dapat disebabkan karena data karakteristik jenis kelamin pada antar kelompok homogen atau tidak memiliki perbedaan. Penelitian Novianti dkk (2019) yang menyatakan jenis kelamin tidak berhubungan dengan kadar asam urat lansia yang mengonsumsi susu dan olahanya.

Pada kedua kelompok dominan lebih banyak subjek dengan jenis kelamin perempuan hal ini dikarenakan perempuan akan mudah mengalami kenaikan kadar asam urat ketika kadar hormone estrogen dalam tubuh menurun. Hormone esterogen mempunyai salah satu bagian terbesar yaitu estradiol. Setiap hari estradiol diproduksi sebanyak 0.09-0.25, ketika masa menopause estradiol hanya diproduksi sekitar $10 \mathrm{pg} / \mathrm{ml}$. Estradiol ini berperan dalam membantu terjadinya ekskresi asam urat melalui ginjal kemudian dikeluarkan dari tubuh melalui urin. Penurunan kadar estradiol pada ketika memasuki masa menopause menyebabkan kadar asam urat semakin tinggi (Mumford, 2013).

Penelitian Aryanti (2018) menunjukkan hal yang sama. Penelitian dilakukan dengan subjek prempuan lebih banyak dibandingkan dengan subjek laki-laki. Penelitian Yunita dan 
Etisa (2016) tentang pemberian kapsul cengkeh terhadap kadar asam urat yang menggunakan subjek wanita. Penelitian Afnuhazi (2019) menggunakan subjek penelitian sebagian besar wanita dibandingkan dengan laki-laki. Tidak ditemukan perbedaan karakteriksik aktifitas pada penelitian ini, diperoleh hasil $\mathrm{p}$ value 0,850 yang menunjukan tidak berbeda signifikan, hal ini dikarenakan data karakteristik pada antar kelompok berupa aktifitas fisik bersifat homogen atau tidak adanya perbedaan antara aktifitas fisik kelompok perlakuan dan aktifitas fisik pada kelompok control. Pada aktifitas fisik dibedakan dengan 3 tingkatan yaitu tingkatan ringan, tingkatan sedang dan tingkatan berat. Pada kelompok kontrol subjek lebih dominan dengan tingkatan kategori aktifitas fisik sedang sedangkan kelompok perlakuan lebih dominan subjek dengan aktifitas fisik dengan kategori ringan. Subjek yang memiliki aktifitas sedang lebih banyak pada ibu rumah tangga. Pada kelompok perlakuan lebih dominan subjek yang memiliki usia lebih muda dibandingkan pada kelompok kontrol, hal ini yang menyebabkan pada kelompok perlakuan lebih dominan memiliki kategori aktifitas fisik ringan, hal ini sesuai dengan perhitungan menggunakan metode PAR (WHO, 2001).

Pada asupan makanan kedua kelompok terdapat perbedaan dibuktikan dengan $\mathrm{p}$ value sebesar 0,040 terdapat perbedaan yang menunjukkan bahwa data karakteristik asupan lemak yang dianalisis bersifat tidak seragam (homogeny) dan adanya perbedaan antara asupan Jurnal Gizi Unimus Vol 10 No 12021 lemak. Kelompok kontrol lebih banyak mengonsumsi asupan lemak yang tinggi. Kelompok kontrol lebih banyak mengonsusmsi makanana berupa lauk yang memiliki kandungan lemak yang tinggi seperti daging sapi, ikan dan telur, hal ini menyebabkan asupan lemak pada kelompok control lebih tinggi disbanding pada kelompok perlakuan. Penelitian Prihatiningsih (2010) juga menyatakan bahwa asupan lemak paling berpengaruh terhadap kadar asam urat karena pengeluaran asam urat dalam tubuh akan terhambt oleh asupan lemak yang tinggi. Risiko sebesar 0,895 kali lebih besar dimiliki oleh seseorang dengan asupan lemak tinggi untuk menderita hiperurisemia dibandingkan dengan orang yang asupan lemak cukup. Penelitian ini dilakukan terhadap sampel berjenis kelamin lakilaki yang memiliki berat badan yang berlebih.

Penelitian ini subjek memilih untuk tidak mengonsumsi obat untuk menurunkan kadar asam urat selama satu minggu atau 7 hari agara subjek dapat mengetahui adanya pengaruh dari sari buah kersen untuk menurunkan kadar asam urat selain mengonsumsi obat.

\section{Kadar Asam Urat}

Tabel 2. Perbedaan Kadar Asam Urat Sebelum (Pre Test) Pemberian Sari Buah Kersen pada Antar Kelompok

\begin{tabular}{llc}
\hline Kelompok & Mean \pm SD & p value \\
\hline Kontrol & $6.5 \pm 0.6$ & 0.017 \\
Perlakuan & $7.4 \pm 1.5$ & \\
\hline
\end{tabular}


Dari Tabel 2 analisis uji Man- Whitney menunjukkan nilai 0,017, artinya adanya perbedaan pada antar kelompok pada saat sebelum intervensi disebabkan karena adanya ketidak seragaman (homogen) kelompok yang dibuktikan dengan adanya perbedaan pada karakteristik usia dan karakteristik asupan lemak antara kelompok pada awal penelitian. Pada kelompok kontrol makanan yang dikonsumsi tidak stabil atau tidak selalu menghindari makanan yang tidak dianjurkan. Hasil pre test kadar asam urat kelompok kontrol 8 subjek terjadi penurunan dan 9 subjek mengalami peningkatan. Pada kelompok kontrol terdapat subjek yang mengonsumsi makanan yang mengandung purin berupa ikan sarden, tempe tahu, dan sayur pecel yang didalamnya terdapat sayur toge dan bayam. Ikan sarden merupakan salah satu makanan yang mengandung purin tinggi (Herliana, 2013). Kandungan purin pada ikan sarden sebesar 124,3 $\mathrm{mg} / 100 \mathrm{~g}$ (Noormindhawati, 2013). Sedangkan kandungan purin pada bayam tergolong purin rendah (Soeroso dan Algristian, 2011).

Tabel 3. Perbedaan Kadar Asam Urat Sebelum dan Sesudah Kelompok Kontrol.

\begin{tabular}{llll}
\hline Kelompok & \multicolumn{2}{c}{ Mean \pm SD } & p value \\
& Pre test & Post test & \\
\cline { 1 - 3 } Kontrol & $6.5 \pm 0.63$ & $6.4 \pm 0.79$ & 0.421 \\
\hline
\end{tabular}

Dari Tabel 3 analisis uji Wilcoxon menunjukkan nilai 0,421 ( $p$ value $<0,05$ ), artinya tidak terdapat perbedaan pada kelompok kontrol. Sampel pre test diambil pada saat sebelum dilakukan pemberian kersen dan data post test dilakukan setelah pemberian kersen. Kelompok Jurnal Gizi Unimus Vol 10 No 12021 kontrol diberi informasi terkait penyebab peningkatan kadar asam urat sebelum dilakukan proses intervensi.

Pada pengecekan kadar asam urat akhir (post test) didapat kan data bahwa hasil kadar asam urat beberapa subjek mengalami peningkatan. Sesuai dengan pengakuan dan penjelasan dari subjek, selama 1 minggu pemantauan subjek tetap mengonsumsi makanan yang mengandung purin tinggi sehingga terjadi peningkatan kadar asam urat yang selalu ada setiap hari yaitu tahu tempe, tahu campur yang berisi jeroan, olahan jagung, ikan sarden, seafood dan lainya. Makanan yang dikonsumsi oleh subjek masih memiliki kandungan purin yang tinggi. Kandungan purin sendiri merupakan protein yang termasuk dalam golongan nucleoprotein. Peningkatan kadar asam urat sebanyak 0,5 sampai dengan $0,75 \mathrm{~g} / \mathrm{ml}$ per gram dari purin yang dikonsumsi per harinya (Yenrina dkk, 2014). Asupan lemak yang tinggi akan mengganggu ekskresi asam urat pada ginjal, asupan lemak yang berlebih dapat menyebabkan obesitas. Obesitas dapat mengganggu kinerja ginjal, kinerja ginjal yang menurun dapat berakibat pada kondisi hiperurisemia (Lingga, 2014). Penelitian Prihatiningsih dan Yekti (2010) menunjukkan hasil adanya hubungan asupan makanan dengan subjek yang mengalami hiperurisemia.

Pada kelompok kontrol juga terdapat subjek yang memiliki usia 60-70 tahun dengan berjenis kelamin prempuan, hal ini dapat meyebabkan peningkatan kadar asam urat 
dikarenakan usia wanita yang semakin menua menyebabkan hormone esterogen berkurang (Lingga, 2012).

Tabel 4. Perbedaan Kadar Asam Urat Sebelum dan Sesudah Pemberian Sari Kersen Kelompok Perlakuan.

\begin{tabular}{llll}
\hline Kelompok & \multicolumn{2}{c}{ Mean \pm SD } & p value \\
\hline & Pre test & Post test & \\
\hline Perlakuan & $7.4 \pm 1.51$ & $6.7 \pm 1.35$ & 0.001 \\
\hline
\end{tabular}

Dari hasil Tabel 4 analisis uji Wilcoxon menunjukkan nilai 0,001 artinya terdapat perbedaan antara sebelum dan sesudah pada kelompok perlakuan, dapat disimpulkan adanya pengaruh pada kelompok perlakuan setelah dilakukan intervensi.

Pada pengambilan post test terjadi penurunan kadar asam urat pada kelompok perlakuan, dikarenakan pada kelompok perlakuan mentaati anjuran dengan mengonsumsi makanan yang tidak boleh dikonsumsi dan hanya mengonsumsi sari buah kersen sebagai makanan selingan disamping makanan utama untuk membuktikan bahwa dengan mengonsumsi buah kersen dapat menurunkan kadar asam urat tanpa mengomsumsi obat-obatan. Hanya terdapat 2 dari 17 subjek pada kelompok perlakuan yang mengalami hal sebaliknya, yaitu peningkatan kadar asam urat.

Subjek yang mengalami peningkatan mengatakan bahwa subjek mengonsumsi jagung serta minuman bersoda. Minuman bersoda selain mengandung fruktosa yang dapat menyebabkan terjadinya hiperurisemia. Eksresi asam urat akan terhambat dikarenakan adanya asam laktat Jurnal Gizi Unimus Vol 10 No 12021 sehingga mengalami peningkatan kadar asam urat darah (Komariah,2015). Makanan yang harus dihindari pada penderita hiperurisemia yaitu minuman yang memiliki fruktosa tinggi, minuman bersoda, dan alcohol (Kalim dkk, 2019). Mengonsumsi minuman bersoda satu gelas/ kaleng dapt meningkatkan resiko terkena asam urat 74\% lebih tinggi (Rasjid, 2018).

Jagung dan sayur bayam juga merupakan makanann yang mengandung tinggi purin. Purin dapat memicu pembentukan kadar asam urat didalam tubuh. Asam urat akan meningkat dengan mengonsumsi makanan mengandung purin dengan kenaikan sekitar 0,5-0,75 $\mathrm{g} / \mathrm{ml}$ (Yenrina,20). Pada penelitian putri (2018) didapatkan hasil adanya pengaruh makanan tinggi purin terhadap kadar asam urat. Selain itu pada penelitian Rosdiana dkk (2018) tentang pengetahuan asam urat mengatakan terdapat hubungan yang signifikat antara kadar purin pada makanan dengan peningkatan kadar asam urat.

Tabel 5. Perbedaan Kadar Asam Urat Sesudah Pemberian Sari Kersen Antar Kelompok

\begin{tabular}{llc}
\hline Kelompok & Mean \pm SD & p value \\
\hline Kontrol & $6.4 \pm 0.79$ & 0.717 \\
Perlakuan & $6.7 \pm 1.35$ &
\end{tabular}

Hasil tabel 5 uji Man-Whitney diperoleh $\mathrm{p}$ value 0,717 artinya dapat disimpulkan tidak terdapat perbedaan kadar asam urat pada antar kelompok perlakuan. kelompok yang tidak diberikan intervensi memiliki rata-rata sebesar yaitu $6,4 \mathrm{mg} / \mathrm{dL}$ atau $>6 \mathrm{mg} / \mathrm{dL}$ yang berarti kadar asam urat masih tinggi (Lingga, 2012). 
Sedangkan pada kelompok yang diberikan intervensi memiliki rata-rata sebesar $6,7 \mathrm{mg} / \mathrm{dL}$ atau lebih besar daripada $6 \mathrm{mg} / \mathrm{dL}$ yang tergolong tinggi (Lingga, 2012).

Kelompok perlakuan terjadi penurunan kadar asam urat sesudah pemberian sari buah kersen, akan tetapi masih tergolong tinggi dikarenakan pada awal penelitian terdapat perbedaan atau ketidakseragaman (homogen) karakteristik usia dan karakteristik asupan lemak subjek pada antar kelompok. Hasil pada perbedaan kadar asam urat sesudah pemberian sari buah kersen yang menunjukkan tidak terdapat perbedaan antar kelompok juga dapat disebabkan adanya konsumsi protein yang tidak berbeda pada antar kelompok. Protein merupakan kalah satu kandungan gizi yang ada pada makanan, protein identik purin yang terkandung didalam makanan yang biasanya berupa jeroan, kacang-kangam, beberapa sayur dan sebagian buah. Kinerja ginjal dapat terganggu oleh tingginya asupan protein karena asipan protein dapat menurunkan ph pada ginjal. Kelebihan mengonsumsi protein dapat menyebabkan sekresi keton dan asam urat akan bersaing melalui ekskresi lewat ginjal sehingga menyebabkan terjadinya kenaikan kadar asam urat darah (Lingga, 2012). Pada kedua kelompok juga masih mengonsumsi sayur kangkung, bayam, daging, ikan dan telur. Penelitian Kussoy dkk (2019) menyatakan adanya hubungan konsumsi purin pada kadar asam urat. Selain mengonsumsi protein dengan purin yang sama kelompok kontrol dan kelompok perlakuan juga mengonsumsi asupan karbohidrat yang sama.

Pada karbohidat sederhana biasanya disebut zat gula (monosakarida dan disakarida), jenis karbohidrat ini biasanya terdapat pada buah , gula, madu, maltose dan hasil olahan seperti sirup, selai dan lainya. Sedangkan pada karbohidrat komplek yang berasal dari padipadian, umbi dan kacangan dapat membantu meningkatkan pengeluaran asam urat melalui urin (Nuari dan Dhina, 2017).

Tabel 6. Perbedaan Selisih Kadar Asam Urat Sesudah pada Antar Kelompok.

\begin{tabular}{llc}
\hline Kelompok & Mean \pm SD & p value \\
\hline Kontrol & $0.112 \pm 0.75$ & 0.004 \\
Perlakuan & $0.676 \pm 0.55$ & \\
\hline
\end{tabular}

adanya perbedaan selisih yang signifikan antara kelompok. Pada kelompok kontrol tetap mengkonsumsi makanan purin tinggi dengan porsi/sama seperti keseharian sehingga dapat memicu peningkatan kadar asam urat. Setelah dilakukan recall terdapat perbedaan pada asupan lemak antara subjek kelompok kontrol dan subjek kelompok perlakuan.

Terjadi perbedaan selisih juga dapat dikarenakan adanya asupan lemak yang berbeda antar kelompok. Konsumsi lemak dapat menyebabkan terjadinya obesitas. Obesitas dapat mengganggu fungsi kerja ginjal sehingga dapat menyebabkan peningkatan kadar asam urat darah(Lingga, 2012). 


\section{Pengaruh Pemberian Sari Buah Kersen terhadap Kadar Asam Urat.}

Hubungan pemberian sari buah kersen terhadap kadar asam urat dibuktikan dengan analisis uji korelasi parsial dan hasil p value 0,001 yang menunjukan adanya hubungan konsumsi sari buah kersen dengan penurunan kadar asam urat pada subjek. Hal ini dibuktikan pada kedua kelompok tidak memiliki perbedaan yang signifikan pada jenis kelamin, aktifitas fisik, asupan energi, asupan protein dan asupan karbohidrat. Perbedaan pada antar kelompok hanya pada variabel karakteristik berupa usia, asupan lemak dan adanya konsumsi sari buah kersen pada kelompok perlakuan.

Penurunan kadar asam urat dengan konsumsi sari buah kersen dikarenakan buah kersen memiliki kandungan kandungan antioksidan serta adanya vitamin $\mathrm{C}$ sejumlah 80,5 mg / 100 gram (Lingga, 2012). Kandungan vitamin $\mathrm{C}$ pada buah kersen juga dapat mengurangi kadar asam urat dalam tubuh dikarenakan vitamin $\mathrm{C}$ meningkatkan pembuangan asam urat melalui urin, akibatnya kadar asam urat urin akan berkurang (Sutanto, 2013).

Setelah dilakukan uji korelasi parsial yang didapatkan hasil terdapat hubungan lalu dilanjutkan dengan uji regresi linier untuk mencari adanya pengaruh dari pemberian sari kersen dengan kadar asam urat. Pada uji regresi linier didapatkan hasil Adsarited R Square sebesar
0,206 atau dengan nilai P value sebesar 0,004. Jadi konsumsi buah kersen memberikan kontribusi dalam menurunkan kadar asam urat sebesar 20,6\%. Hal ini juga menunjukkan bahwa pada kadar asam urat subjek mengalami penurunan yang disebabkan oleh faktor usia dan asupan lemak selain konsumsi sari buah kersen.

Berdasarkan penelitian dan analisis yang dilakukan dapat disimpulkan pemberian sari buah kersen sebanyak 40,5 g/ hari selama 7 hari dapat menurunkan kadar asam urat subjek penelitian pada kelompok perlakuan. Kondisi hiperurisemia dapat diringankan dengan konsumsi vitamin $\mathrm{C}$. Vitamin $\mathrm{C}$ dapat mingkatkan sekresi asam urat melalui urin sehingga dapat memperbaiki konsidi hiperurisemia (Seoroso, 2011).

Vitamin $\mathrm{C}$ mempunyai sifat urikosurik yang dapat mengurangi jumlah kristal asam urat. Urikosurik dapat menghambat penyerapan asam urat oleh ginjal, kemuaidan meningkatkan pembersihan fraksional asam urat ginjal sehingga dapat meningkatkan laju pada kerja ginjal dalam mengekresikan asam urat melalui urin. Vitamin C juga dapat memberikan pertahanan sehingga mencegah proses peradangan (Ikawati, 2010).

Asam urat yang tidak dipakai akan diteruskan ke kapsula bowmen, dari kapsula bowmen akan diteruskan ke ureter, dari ureter akan diteruskan ke visika urinaria. Visika urinaria akan mengeluarkan asam urat yang tidak dipakai bersama urin melalui uretra (Almatsier, 2003). Penelitian ini memiliki kesamaan hasil dengan 
penelitian Kholifaturrohma (2016) yang menyatakan terdapat hubungan penurunan kadar asam urat pada mencit yang hiperurisemia akibat Pemberian Ektrak Buah Kersen. Penelitian Anisa (2018) Tentang Sari Buah Kersen Terhadap Kadar Asam Urat Mencit yang mendapatkan hasil terdapat pengaruh pemberian sari buah kersen terhadap kadar asam urat mencit.

\section{KESIMPULAN DAN SARAN}

\section{Kesimpulan}

1. Terdapat perbedaan Pre Test pada antar kelompok.

2. Tidak terdapat perbedaan Pre Test dan Post Test kelompok kontrol.

3. Terdapat perbedaan Pre Test dan Post Test kelompok perlakuan.

4. Tidak Terdapat perbedaan kadar asam urat Post Test pada antar kelompok.

5. Terdapat selisih kadar asam urat pada antar kelompok.
6. Terdapat pengaruh antara konsumsi sari buah kersen dengan kadar asam urat sebesar 20,6\% dengan menggunakan uji regresi linier

\section{Saran}

1. Penelitian selanjutnya dapat lebih lanjut dengan uji kadar asam urat menggunakan uji laboratorium.

2. Penelitianselanjutnya mampu mempertimbangkan faktor perancu seperti kandungan purin dalam makanan, cairan, status gizi dan obat yang dikonsumsi.

3. Penelitian selanjutnya diharapkan mampu menyeragamkan subjek disetiap kelompok dengan mempertimbangkan setiap variabel yang digunakan.

\section{Ucapan Terima Kasih}

Terimakasih untuk orang tua, saudara, dosen pembimbing, teman dan semua orang yang sudah membantu dalam penyelesaian penelitian $\mathrm{i}$ 


\section{DAFTAR PUSTAKA}

Afnuhazi, R. 2019. "Faktor-Faktor Yang Berhubungan Dengan Kejadian Gout Pada Lansia”. Jurnal Human Care ;Vol 4 (1)

Almatsier, S., 2003. Prinsip Dasar Ilmu Gizi. Jakarta: PT. Gramedia Pustaka Utama.

Amina, MS. 2012. Ajaibnya Terapi Herbal Tumpas Penyakit Asam Urat. Cetakan ke 1. Jakarta Timur: Dunia Sehat.

Aryanti, Oktania. 2018. Pengaruh Pemberian Perasan Buah Strawberry (Fragaria Virginiana Duchesne) Terhadap Perubahan Kadar Asam Urat Penderita Hiperurisemia. Skripsi. Politeknik Negeri Jember.

Apriyanti M. 2013. Menu Sehat bagi Penderita Asam Urat. Yogyakarta: PustakaBaru.

Diantari, Ervi., Aryu C. 2012. "Pengaruh Asupan Purin Dan Cairan Terhadap Kadar Asam Urat Wanita Usia 50-60 Tahun di Kecamatan Gajah Mungkur, Semarang”. Journal of Nutrition College ; 2(1) : 44-49

Herlina, Ersi. 2013. Penyakit Asam Urat Kandas Berkat Herbal. Jakarta Selatan: Penerbit Fmedia

Kalim,H., Singgih Wahonp., Perdana Ragma. 2019. Reumatologi Klinik. Malang: UB Press

Karuniawati, Benny. 2018. "Hubungan Usia Dengan Kadar Asam Urat Pada Wanita Dewasa". Jurnal Kesehatan Madani Medika. Vol 9 (2)

Kholifaturrokhmah, Ida., Ratna Damma Purnawati. 2016. "Pengaruh
Pemberian Ekstrak Buah Kersen (Muntingia Calabura L.) Dosis Bertingkat Terhadap Gambaran Histopatologi Ginjal Mencit Balb/C Yang Hiperurisemia”. Jurnal Kedokteran Diponegoro Semarang; $5(3)$.

Komariah, Anis. 2015. Pengaruh Senam Ergonomis Terhadap Kadar Asam Urat Pada Lansia Dengan Gout Di Pos Binaan Terpadu Kelurahan Pisangan Ciputat Timur. Skripsi. Fakultas Kedokteran Dan Ilmu Kesehatan Universitas Islam Negeri Syarif Hidayatullah. Jakarta.

Kussoy, V.F., Rina,K., Ferdinand, W. 2019. Kebiasaan Makan Makanan Tinggi Purin Dengan Kadar Asam Urat Di Puskesmas. Journal Keperawatan (J-Kp) Vol 7 (2). Universitas Sam Ratulangi

Lingga, L. 2012. Bebas Penyakit Asam Urat Tanpa Obat. Cetakan ke-1. Jakarta: Agro Media Pustaka.

Lioso, JP., Ricky, CS., Budi, TR. 2015. Hubungan Antara Umur, Jenis Kelamin Dan Indeks Massa Tubuh Dengan Kadar Asam Urat Darahpada Masyarakat Yang Datang Berkunjung Di Puskesmas Paniki Bawah Kota Manado. Fakultas Kesehatan Masyarakat Universitas Sam Ratulangi

Mumford, S., Dasharathy, S. "Serum Uric In Relation To Endogenous Reproductive Hormones During The Menstrual Cyle”. Jurnal Stikes Mucis

Noormindhawati, L. 2013. Penyakit Asam Urat.

Bandung : Pustaka Makmur.

Nuari NA, Widayati D. 2017 . Sistem Perkemihan dan Penatalaksanaan Keperawatan. Sleman: Budi Utama.

Olivia, Femi. 2014. Organic Moster Drinks. Jakarta: PT Elex Media Komputindo.

Pangkal Ide. 2012. Agar Pankreas Sehat. Jakarta: 
PT Elex Media Komputindo

Peraturan Menteri Kesehatan RI. 2012. Registrasi Obat Tradisional. No. 007

Putri, Mira. 2018. "Hubungan Asupan Purin Dengan Kadar Asam Urat Pada Masyarakat Usia 30-

50 Tahun Di Padukuhan Bedog Trihanggo Gamping Sleman Yogyakarta ”. Jurnal Ilmu Keperawatan.

Pursriningsih, SS., Binar, P. 2015. "Hubungan Asupan Purin, Vitamin C Dan Aktivitas Fisik". Jurnal of Nutrition College. Vol 4 (1)

Rasjid, Fadjar Efendy. 2018. Waspadai Berbagai Penyebab Penyakit Asam Urat. Ubaya. Surabaya

Rini. 2017. Hubungan Jenis Kelamin Dan Asupan Purin Dengan Kadar Asam Urat Pada Lansia Di Posyandu Peduli Insani Mendungan Desa Pabelan Kecamatan Kartasura Kabupaten Sukoharjo. Skripsi. Jurusan Ilmu Gizi Fakultas Ilmu Kesehatan. Universitas Muhammadiyah Surakarta.

Riset Kesehatan Dasar. 2013. Prevalensi Penyakit Sendi. Jakarta. Kementerian Kesehatan Republik Indonesia

2018. Prevalensi Penyakit

Sendi.

Kementerian Kesehatan RI. Jakarta

----------, 2007. Kebijakan Obat Tradisional Nasional. Kementerian Kesehatan RI. Jakarta

Risnanto dan U. Insani. 2014. Buku Ajar Asuhan Keperawatan Medikal Bedah: Sistem Muskuloskeletal. Yogyakarta: Deepublish.

Rosdiana, DS., Ali, S., Cesilia, MD. 2018. "Pengetahuan Asam Urat, Asupan Purin Dan Status Gizi Terhadap Kejadian Hiperurisemia Pada Masyarakat Perdesaan”. Jurnal Media Pendidikan, Gizi dan Kuliner. Vol 7 (2)
Rohmawati, AS. 2018. "Sari Kersen (Muntingia Calabura L.) Terhadap Perubahan Kadar Asam Urat Dalam Darah Pada Mencit (Mus Musculus)". E-Journal Analis Kesehatan. Vol 7 (2).

Sanet, I Made Ratih., I Made Oka A.P., I Wayan Sudiarta. 2017. Kandungan Total Fenol Dan Flavonoid Dari Buah Kersen (Muntingia Calabura) Serta Aktivitas Antioksidannya. Program Studi Kimia Universitas Udayana.

Simatupang,Mutiara. 2011. Isolasi Senyawa Flavonoida dari Kulit Batang Tumbuhan Seri (Muntingia Calabura L.). Universitas Sumatra Utara.

Susanto, Hari. 2018. Asuhan Keperawatan Pasien Gout Arthritis Pada Tn. $M$ dan Ny. S Dengan Masalah Keperawatan Nyeri Akut Di UPT Jember. Fakultas Keperawatan. Jember

Soeroso J \& Algristian H. 2011. Asam Urat. Depok Jakarta: Penebar Plusa

Untari, Ida., Siti Sarifah., Sulastri. 2017. Hubungan Antara Penyakit Gout dengan Jenis Kelamin dan Umur pada Lansia. Skripsi. Universitas Muhammadiyah Magelang.

Yenrina, Rina., Diah Krisnatuti., Dini Rasjmida. 2014. Diet Sehat untuk Penderita Asam Urat. Cetakan ke-1. Jakarta Timur : Penebar Swadaya.

Yunita, RD., Etisa. 2016. Pengaruh Pemberian Kapsul Cengkih Terhadap Kadar Asam Urat Pada Wanita Prediabetes. Journal Of Nutrition College, Vol 5(3) 